\title{
Eagle's syndrome presenting as a cervical mass
}

Sami Kouki, ${ }^{1}$ Mouna Guerfel ${ }^{2}$

${ }^{1}$ Medicine Faculty of Tunis, Rades, Tunisia ${ }^{2}$ Military Hospital of Tunis, Montfleury, Tunisia

\section{Correspondence to} Dr Sami Kouki, koukisemi@yahoo.fr

\section{DESCRIPTION}

We report a case of an 84-year-old man who had completely recovered from Hodgkin's disease and was consulting, after 2 years, for severe odynophagia. Clinical examination showed a left cervical mass associated with a bilateral filling tonsillar fossa. A relapse with a cervical compressive lymph node was suspected. An elongated styloid process, particularly on the left side, was identified on a CT scan.

Multiplanar reconstructions (figure 1), volume rendering (figure 2) and maximum intensity projection (figure 3) CT reconstructions showed bilaterally elongated styloid processes $>30 \mathrm{~mm}$ in length and left stylohyoid ligament ossifications.
Eagle's syndrome (ES) was therefore diagnosed. Skin surface method CT scan reconstruction and a photograph of the cervical region of the patient (figure 4) showed a left cervical mass.

ES, sometimes called styloid or stylohyoid syndrome, is defined as the symptomatic ossification of the stylohyoid ligament and/or elongated styloid process $>30 \mathrm{~mm}^{1-3}$ Despite its frequency, ES is still underestimated by clinicians. Its pathogenesis remains obscure and its symptoms are variable. Its diagnosis is clinical and radiological. Because ES symptoms are variable and non-specific, it is very important for all clinicians to include it in the differential diagnosis when treating patients with an atypical headache, neck pain or cervical mass as in our case.
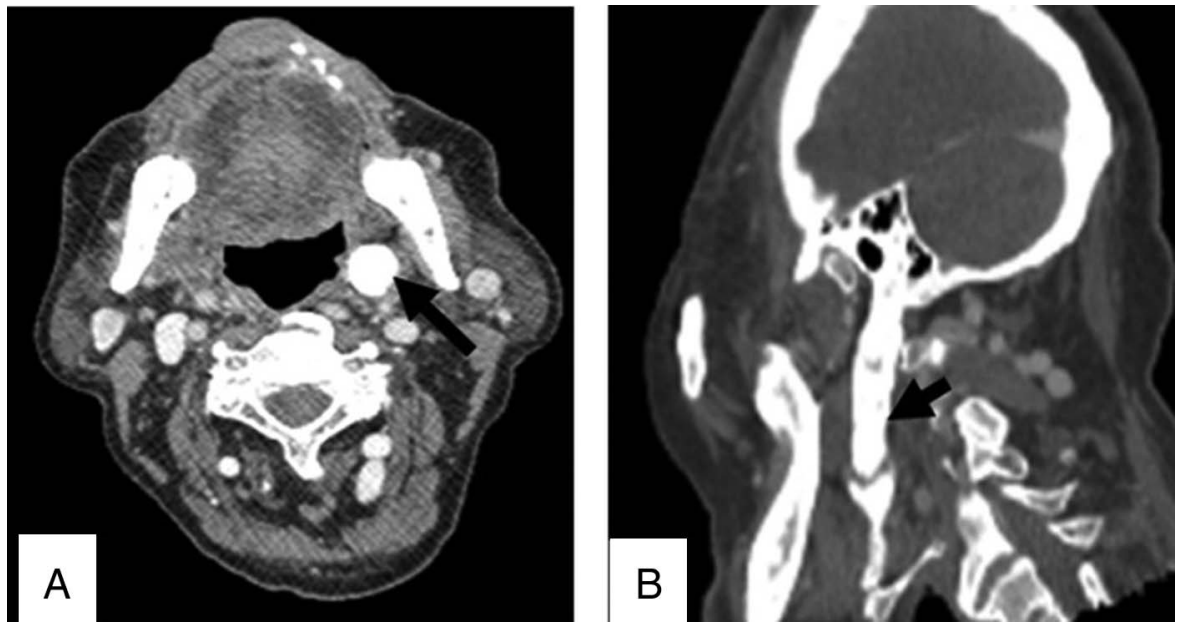

Figure 1 CT scan: transverse (A) and oblique (B) reconstructions showing left elongated styloid process (arrow).
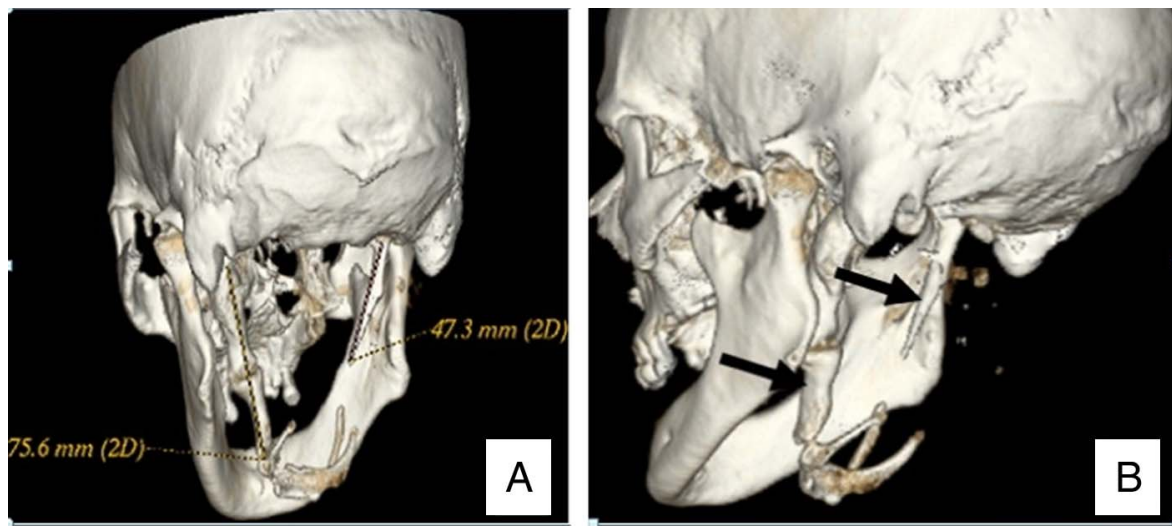

Figure 2 ( $A$ and $B$ ) Volume rendering reconstruction showing bilaterally elongated styloid processes and left stylohyoid ligament ossification (arrow). 2D, two-dimensional. 


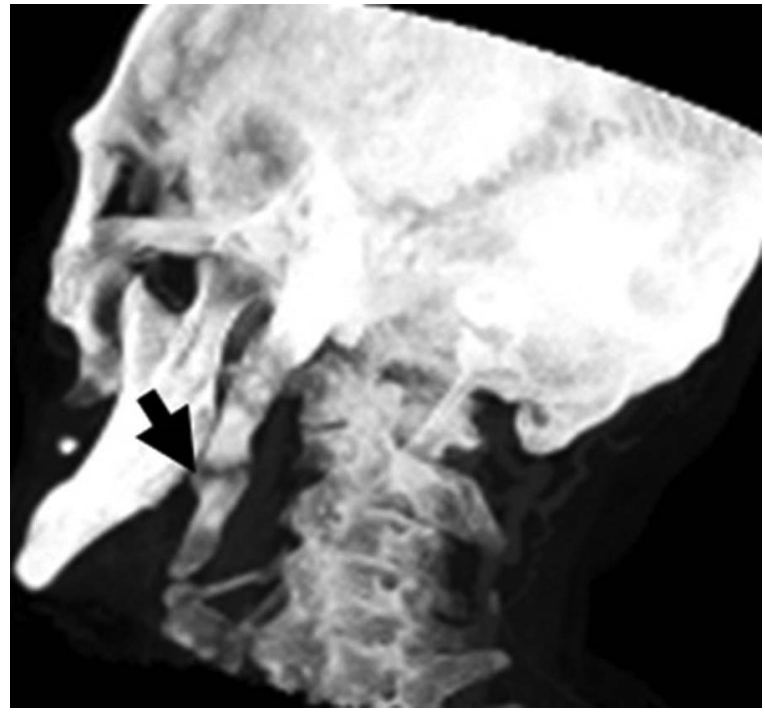

Figure 3 Oblique maximum intensity projection reconstruction showing left elongated styloid process (arrow).
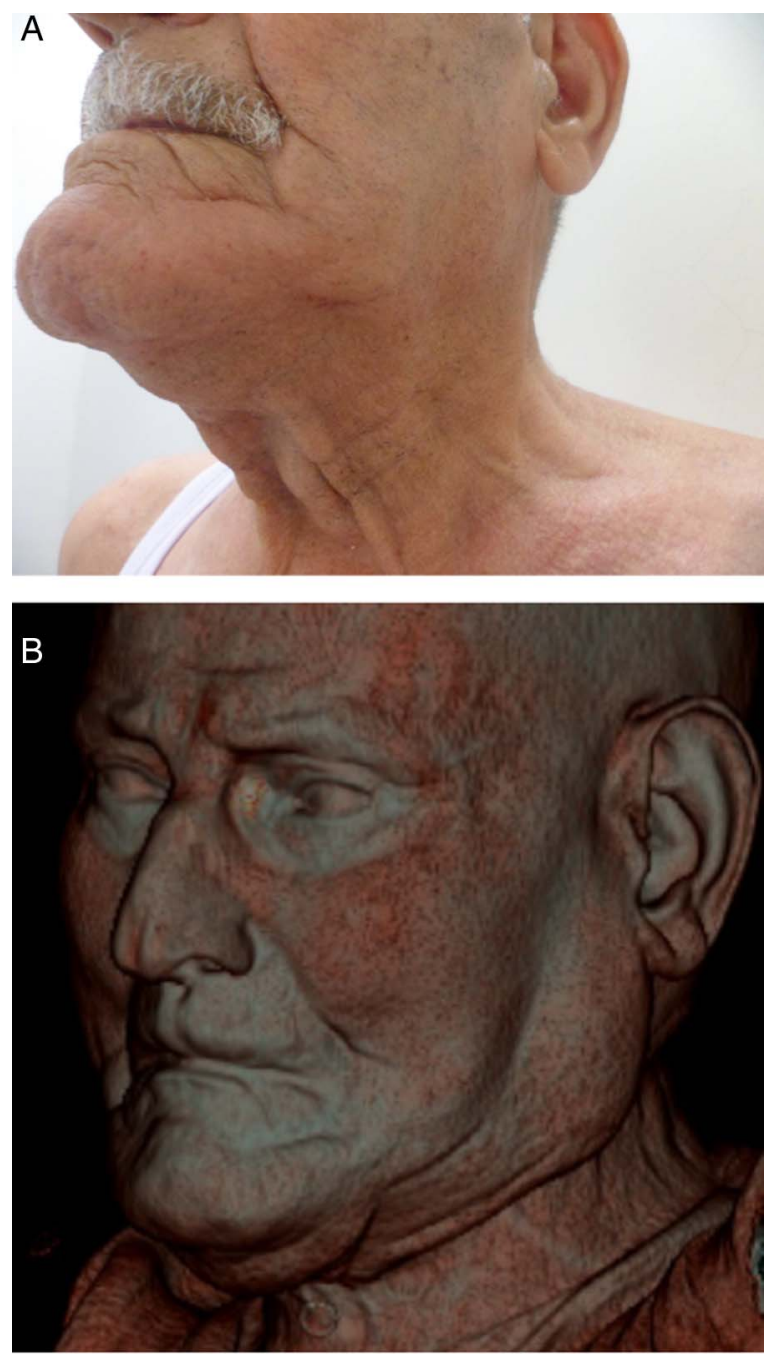

Figure 4 Left oblique photograph of the cervical region of patient (A) and a skin surface method CT scan reconstruction (B) showing a left cervical mass.

\section{Learning points}

- It is important to point out that an elongated stylohyoid process does not necessarily translate into Eagle's syndrome.

- The diagnosis of Eagle's syndrome must be accompanied by an elongated stylohyoid process or calcification of the stylohyoid ligament and clinical symptoms.

- It is very important for all clinicians to include Eagle's syndrome in the differential diagnosis when treating patients with atypical pain in the head and neck regions.

Competing interests None.

Patient consent Obtained.

Provenance and peer review Not commissioned; externally peer reviewed.

\section{REFERENCES}

1 Eagle WW. Elongated styloid processes: report of two cases. Arch Otolaryngol 1937:25:584-7.

2 Eagle WW. Elongated styloid process: further observations and a new syndrome. Arch Otolaryngol 1948;47:630-40.

3 Correll RW, Jensen JL, Taylor JB, et al. Mineralization of the stylohyoid-stylomandibular ligament complex: a radiographic incidence study. Oral Surg Oral Med Oral Pathol 1979;48:286-91. 
Copyright 2013 BMJ Publishing Group. All rights reserved. For permission to reuse any of this content visit http://group.bmj.com/group/rights-licensing/permissions.

BMJ Case Report Fellows may re-use this article for personal use and teaching without any further permission.

Become a Fellow of BMJ Case Reports today and you can:

- Submit as many cases as you like

- Enjoy fast sympathetic peer review and rapid publication of accepted articles

- Access all the published articles

- Re-use any of the published material for personal use and teaching without further permission

For information on Institutional Fellowships contact consortiasales@bmjgroup.com

Visit casereports.bmj.com for more articles like this and to become a Fellow 